\title{
Study of Virioplankton Abundance and Morphological Diversi- ty in a Brazilian Coastal Region Influenced by Upwelling System
}

\author{
Juliana Eymara Fernandes Barbosa ${ }^{*}$, Priscila Santana Pereira ${ }^{1}$, Lorena da Graça Pedrosa de Macena ${ }^{1}$, \\ Bernardo Freitas Paula', Vinícius Vogel ${ }^{2}$, Aguinaldo Marques Nepomuceno ${ }^{2}$, Mirian de Araujo Carlos \\ Crapez $^{3}$, Davis Fernandes Ferreira ${ }^{4}$, Lidia Maria Fontes Amorim ${ }^{1}$, Viveca Antônia Giongo ${ }^{1}$, Izabel Christina \\ Palmer Paixao ${ }^{1}$

\begin{abstract}
${ }^{1}$ Laboratory of Molecular Virology, Departament of Biology Cell and Molecular, Biology Institute, Institute of Biology, Fluminense Federal University, Niterói, Brazil

${ }^{2}$ Laboratory of Biogeochemistry Aquatic Environments, Department of Marine Biology, Institute of Biology, Fluminense Federal University, Niterói, Brazil

${ }^{3}$ Marine Microbiology Laboratory, Department of Marine Biology, Institute of Biology, Fluminense Federal University, Niterói, Brazil ${ }^{4}$ Laboratory of Molecular Biology, Institute of Microbiology Paulo de Goes, Federal University of Rio de Janeiro, Rio de Janeiro, Brazil
\end{abstract}

*Corresponding Author: Juliana Eymara Fernandes Barbosa, Laboratory of Molecular Virology, Department of Biology Cell and Molecular, Biology Institute, Institute of Biology, Fluminense Federal University, Niterói, Brazil-CEP: 24020150, Tel: 55 21 2629-2342/2629-2280; E-mail: julianaeymara@uol.com.br

\begin{abstract}
Marine viruses are among the most common, abundant and diverse biological entities in seawater columns. Despite this, little is yet know about virus abundance and distribution in tropical aquatic ecosystems. Here, we evaluated virus abundance and their relationship to host and environment variables within Arraial do Cabo upwelling system, Rio de Janeiro State, Southeast of Brazil. Seawater samples were collected in four seasonal campaigns from five sampling sites including different areas of human settlement characterized by anthropogenic activity (sewage disposal/ port activity) and upwelling phenomena. Virioplankton abundance ranged from 0.79 to $7.95 \times 10^{8}$. part. $\mathrm{mL}^{-1}$, whereas bacterioplankton abundance ranged from 2.6 to 13.4 $\mathrm{x}$ 107.cell.mL-1. Viruses distribution was evaluated in relation to their possible hosts, and viral abundance positively correlated with both bacteria $(\mathrm{r}=0.65 ; p<0.01)$ and chlorophyll-a $(\mathrm{r}=0.61 ; p<0.01)$. Additionally, a method of concentration using adsorption/elution into electronegative membrane combined to electron microscopy, revealed the presence of bacteriophages, belonging to Myoviridae and Podoviridae families. Principal component analysis showed clear evidence that there is a seasonal influence between Arraial do Cabo biotic and abiotic variables, and that the high abundance of viruses was correlated mainly with nitrogen inorganic forms $\left(\mathrm{NO}_{2}\right.$ - and $\left.\mathrm{NO}_{3}{ }^{-}\right), \mathrm{PO}_{4}^{3-}$, chlorophyll-a and bacteria. Thus, our study indicated that viral abundance in Arraial do Cabo coastal region depends on host cell abundance, which appears to be controlled mainly by nutrient availability.
\end{abstract}

Received date: March 04, 2016

Accepted date: March 26, 2016

Published date: March 28, 2016

Citation: Barbosa, J.E.F., et al. Study of Virioplankton Abundance and Morphological Diversity in a Brazilian Coastal Region Influenced by Upwelling System. (2016) J Marine Biol Aquacult 2(1): 1- 10.

\section{DOI: 10.15436/ 2381-0750.16.013}

Keywords: Virioplankton; Bacterioplankton; Abundance; Morphological diversity; Environmental factors; Upwelling system; Arraial do Cabo

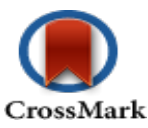

\section{Introduction}

Viruses has been described as the most abundant biological and dynamic components in different aquatic ecosystem $\mathrm{s}^{[1-6]}$ having their greatest reservoir in oceans, where the concentration ranges from $10^{7}$ to $10^{9} \mathrm{~mL}^{-1}[7-10]$.

Several studies on virus abundance and distribution have been performed in polar regions as the $\mathrm{Arctic}^{[11-13]}$ and Antarctica ${ }^{[8,14]}$, and also in different temperate and tropical ocean portions, as Pacific ${ }^{[9,15,16]}$ and Atlantic ${ }^{[4,17,18]}$. However, few virus ecology studies have addressed the assessment of virioplankton community in tropical aquatic ecosystems ${ }^{[4,19]}$. Only two works on the coast of the State of Sao Paulo ${ }^{[20,21]}$, two in the Amazon region ${ }^{[22,23]}$ and one in the upwelling system of Rio de Janeiro describe about virus ecology in Brazilian aquatic ecosystems ${ }^{[24]}$. The reason is that environmental virology studies are generally focused on aspects of public health and disease-causing agents, not on ecological aspects ${ }^{[25-29]}$.

Although it is known that virioplankton plays an important role in ecological and biogeochemical processes such as bacterial mortality and nutrients ${ }^{[30-33]}$, it is yet little known about the influence of Brazilian upwelling system on microbial abundance present in areas of such upwelling ${ }^{24,34]}$. Moreover, the interactions between virioplankton and bacterioplankton have been investigated worldwide, and it is evident that microbial composition of a region can vary due to many environmental factors ${ }^{[1,35,36]}$. So we 
carried out a seasonal and spatial survey to assess virioplankton abundance and observe their relation to bacterial abundance and environmental factors in the marine seawater of Arraial do Cabo upwelling coastal region.

In such context, this study is regarded as of great importance, once it presents an attempt to elucidate the abundance of marine virioplankton in Arraial do Cabo, Rio de Janeiro tropical upwelling region and also this distribution relationship with the bacterioplankton abundance as well as with environmental variables.

\section{Materials and Methods}

Study area and Sampling: The study area is located at the coastal region of Arraial do Cabo (AC) on the North coast of Rio de Janeiro State, Brazil (Figure 1). This region is known for its elevated marine productivity due to the upwelling phenomenon occurs more frequently during the summer (from September to April). The phenomenon of coastal upwelling is mainly caused by wind action consisting of ocean surface waters thermal anomaly, when water becomes cold and nutrient-rich due to deep South Atlantic Central Water (SACW) penetration and upwelling ${ }^{[37-40]}$. In addition to periodic upwelling, this region is subjected to different anthropogenic pressures such as sewage discharge from domestic sources, industrial effluents, chemical accidents, drilling spills, port activities and others anthropic activities that can also influence the distribution and role of viruses within marine environment under different tropic conditions.

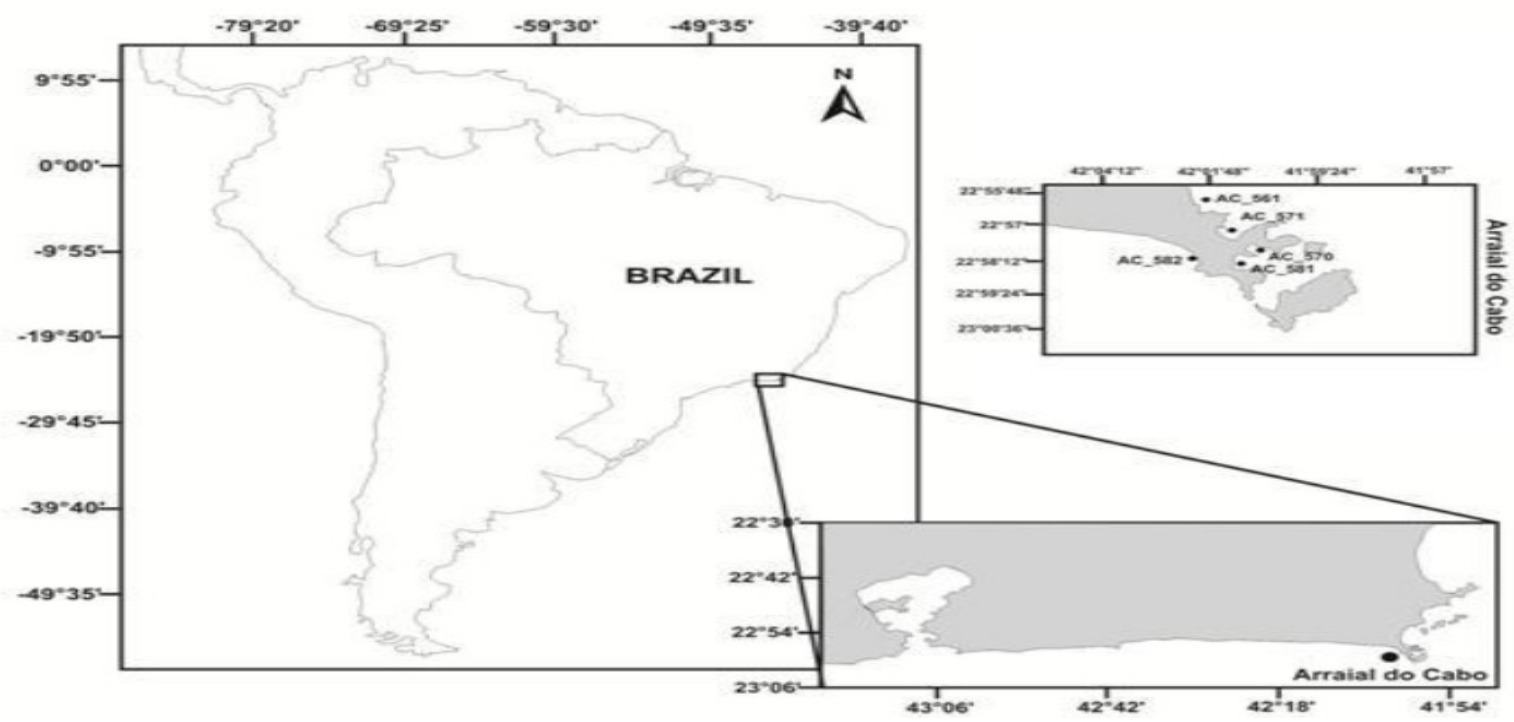

Figure 1: Map for sampling collection. Coastal area of Arraial do Cabo, Rio de Janeiro State, Brazil.

Black spots indicate the position of sampling sites where seawater was collected.

The locations of the sample sites are indicated in Figure 1 and were chosen to represent distinct Influence of hydrological and physical-chemical parameters. Site AC581 (Anjos Bay) and AC570 (Forno Bay) are more sheltered stations located near area of dense population and under more influenced anthropogenic activities. The other three sampling sites (AC571, AC582 and AC561) were located within a more external portion of $\mathrm{AC}$ region, therefore receiving lesser input of anthropogenic activities and higher oceanic environment influence.

A total of 20 seawater samples (25 litres per sample) were collected based on four seasonal Campaigns from five sampling sites conducted between September 2013 and June 2014, according to the annual occurrence of upwelling phenomenon in Arraial do Cabo, which usually begins in September and shows a peak in December during the summer season, while down welling periods are more frequent during the winter.

Subsurface seawater samples were collected with a Van Dorn bottle and performed at neap tide cycle during the day. All samples were transported in polyethylene bottle, protected from light. For virus and bacteria abundance analyses, samples were immediately fixed with glutaraldehyde solution $\left(2 \%\right.$, final concentration) and subsequently stored at $-80^{\circ} \mathrm{C}$ until analysis. While samples for virioplankton characterization, samples were submitted to a concentrated step by the adsorption-elution method, with negatively charged membranes.

Environmental Parameters: At each sampling site, temperature, salinity and conductivity were measured using a YSI 30 probe. Dissolved oxygen (DO) and pH were measured with portable probes: an Oxi 330i set mode WTW oximeter and a model 330i WTW $\mathrm{pH}$ meter. In the laboratory, for nutrients and chlorophyll-a analyses, seawater samples $(2 \mathrm{~L})$ were directly filtered through cellulose acetate membranes $(0.45 \mu \mathrm{m}, 47 \mathrm{~mm} \varnothing$, Millipore), using a vacuum pump, to separate the dissolved and particulate material, then stored at $4^{\circ} \mathrm{C}$ until analyses. Analyses of the dissolved inorganic nitrogen (DIN) - ammonium $\left(\mathrm{N}_{-} \mathrm{NH}_{4}{ }^{+}\right)$, nitrite $\left(\mathrm{N}_{-} \mathrm{NO}_{2}-\right)$ and nitrate $\left(\mathrm{N}_{-} \mathrm{NO}_{3}{ }^{-}\right)$and phosphate ( $\left.\mathrm{P}_{-} \mathrm{PO}_{4}{ }^{3-}\right)$, with aliquots of $100 \mathrm{~mL}$ of filtered subsample, were performed following standard colorimetric techniques according to Grasshoff et $\mathrm{al}^{[41]}$. The material retained on the filters was used for chlorophyll-a analyses, two filters per sample. The filters were sheltered from light until extraction and chlorophyll analysis. After extraction in $90 \%$ acetone for $18 \mathrm{~h}$ at 
$4^{\circ} \mathrm{C}$, the chlorophyll concentrations were determined fluorometrically using a fluorescence spectrophotometer as described by Parsons et al. The concentrations were calculated using equations developed by Lorenzen ${ }^{[42]}$.

Bacterioplankton Abundance: Bacterial counts were performed on samples preserved in 2\% glutaraldehyde ${ }^{[43]}$. In the laboratory, $2.0 \mathrm{~mL}$ of seawater was stained with acridine orange $(0.1 \% \mathrm{w} / \mathrm{v})$ filtered at $20 \mathrm{kpa}$ onto (replicate) $0.2 \mu \mathrm{m}$ pore size polycarbonate (Nucleopore) filters and counted by epifluorescence microscopy under blue excitation with an Axiops 50 Zeiss epifluorescence microscope.

Virioplankton Abundance: At the beginning, to enumerate seawater viruses, sample triplicates were immediately fixed on board with glutaraldehyde ( $2 \%$ final concentration) from each sampling site, and stored in darkness at $4{ }^{\circ} \mathrm{C}$ until analyses. The samples were counted by EpiFluorescence Microscopy (EFM), as described by to Noble and Fuhrman ${ }^{[44]}$ and by Flow Cytometry (FCM) following recommendations of Marie et $\mathrm{al}^{[45]}$ and Brussard ${ }^{[46]}$. For both methods we used the label SYBR Green I (molecular ProbeInvitrogen) (Molecular Probes Inc., Eugene, OR, USA), which specifically stains double-stranded DNA.

Epifluorescence Microscopy: Seawater samples $(2 \mathrm{~mL})$ for EFM technique were filtered through $0.02 \mu \mathrm{m}$ pore size $(25 \mathrm{~mm}$ diameter) anodisc aluminum oxide filters (Whatman, Millipore) under 20-kPa vacuum, stained with a dilution of SYBR Green I (Molecular Probes Eugene, OR, USA) 1:10 by mixing $2.5 \mu \mathrm{L}$ of 10\% of SYBR-Green I working solution with $97.5 \mu \mathrm{L}$ of sterile deionized water on the bottom of a sterile plastic petri dish and incubated for $15 \mathrm{~min}$ in darkness. Then, each anodisc filter was mounted on a glass slide with an anti-fading solution consisting of $0.1 \%$ p-phenylediamine (Sigma Chemical Co., made freshly from frozen $10 \%$ aqueous stock) in 50\% glycerol-50\% phosphate-buffered saline (PBS, $0.05 \mathrm{M} \mathrm{Na}_{2} \mathrm{HPO}_{4}, 0.85 \% \mathrm{NaCl}$, pH 7.5). All slides were immediately counted and a total of 30 fields per filter were selected by using an Axiops50, Zeiss epifluorescence microscope under blue excitation ( 450 to $480 \mathrm{~nm}$ ).

Flow Cytometry: Virus concentrations were also measured in parallel in an Accuri C6 flow cytometer (Accuri C6 Flow Cytometer System) equipped with an air-cooled laser $(488 \mathrm{~nm})$ and with a standard filter setup (FL1 at $533 \pm 30 \mathrm{~nm})$. To enumerate virioplankton, samples were thawed for a few minutes and then diluted 1:10 to 1:200 in TE buffer (10mM Tris-HCl and 1mM EDTA, pH 8) to avoid coincidence on the flow cytometer, and incubated with SYBR Green I (at a commercial stock solution final concentration of $5 \times 10^{-4}$, Molecular Probes Eugene, OR, USA), for $10 \mathrm{~min}$ at $80^{\circ} \mathrm{C}$ in darkness, prior to FCM analysis. Sterile seawater and dilution medium were also used as blank. Samples were run for 1 to 4 min at a delivery rate of $50 \mu \mathrm{L} . \mathrm{min}^{-1}$ and the discriminator was set on green fluorescence. Readings were performed on logarithmic scales and analyzed with appropriate software.

Virus Concentration: A total of $20 \mathrm{~L}$ of seawater from each sample was concentrated by the method as described by Katayama et $a l^{[47]}$. Briefly, seawater samples were firstly $\mathrm{pH}$ adjusted and subjected to a clarifying process with pre-filters AP-20 ${ }^{\circledR}(142 \mathrm{~mm}$ diameter membrane, Millipore ${ }^{\circledR}$ ) through a filtration system (Millipore ${ }^{\circledR}$, Brazil). Then, the same $20 \mathrm{~L}$ was submitted to another filtration through a type HA membrane negatively charged (Millipore) with a $0.45 \mu \mathrm{m}$ porosity size with a vacuum pump system. The membrane was washed with $350 \mathrm{~mL}$ of $0.5 \mathrm{mM} \mathrm{H}_{2} \mathrm{SO}_{4}(\mathrm{pH} 3.0)$ solution to ensure the retention of viral particles. The next step comprised a viral elution which consisted in releasing the virus from the membrane, which was performed using $15 \mathrm{~mL}$ of $1 \mathrm{mM}$ $\mathrm{NaOH}(\mathrm{pH} 10.5)$. The samples were neutralized with the addition of $50 \mu \mathrm{L}$ each mf $50 \mathrm{mM} \mathrm{H}_{2} \mathrm{SO}_{4}(\mathrm{pH} 3.0)$ and $100 \mathrm{X} \mathrm{TE} \mathrm{buffer} \mathrm{(pH}$ 8.0). The eluate was concentrated using a centriprep YM 50 (Millipore) and centrifuged at $1.500 \mathrm{x} \mathrm{g}$ for $10 \mathrm{~min}$ at $4^{\circ} \mathrm{C}$, obtaining a final volume of $2 \mathrm{~mL}$. The samples were stored at $-80^{\circ} \mathrm{C}$ until they were subjected to morphological analyses.

Morphological Characterization: Virioplankton samples obtained after adsorption-elution steps and concentration method were mixed with glutaraldehyde $2 \%$ and examined by electron microscopy. Virus identification was done according to virus particle ultrastructure as outlined by the International Committee for Taxonomy of Viruses ${ }^{[48,49]}$. Phage samples were incubated for 30 min at carbon-coated copper grid (400 mesh), and afterwards the grid was negatively stained with $1 \%$ uranyl acetate for 1 min. The phage particles were visualized with a Morgani electron microscopy, operating at $100 \mathrm{kV}$ (FEI Co. Hillsboro, OR, USA) and the electron micrographics were recorded with a charge-coupled-device camera.

Statistical Analysis: Parameters from each sampling station were separately analyzed applying descriptive statistics. Data integration was performed using multivariate analyses achieved with "STATISTICA (Statsoft $\left.{ }^{\circledR}\right)$ " software. Arraial do Cabo data was gathered on a matrix to summarize the environment main characteristics. Normally distributed data correlation coefficient (r) was calculated by Pearson's analyses (significant when $\mathrm{p}=0.05$ ), then used to assess potential relationships between selected variables. Principal Component Analysis (PCA) was assessed as an ordering method from correlations between physical, chemical and biological seawater from the sampling sites in different studied periods, in order to indicate the relative significance of predictive variables. These two ultimate statistical analyzes were performed using the "PAST" software. Furthermore, analysis of variance (ANOVA) was performed to detect whether analyzed variables as temperature, $\mathrm{pH}$, salinity, conductivity, dissolved oxygen, chlorophyll-a, nutrients, virus and bacteria abundance and virus-to-bacterium ratio (VBR) varied according to seasonal as well as to spatial locations with different sampling stations. When significant differences were found, the Tukey post-hoc test was applied to determine the sampling station and season analyzed. 


\section{Results and Discussion}

Brazilian coast presents a great variety of ecosystems. We have chosen Arraial do Cabo region because it contains several climatic, geological and ecological peculiarities and stands out as the location in southeastern Brazilian coast where upwelling events occur ${ }^{[24,37,50]}$, more frequently between spring and summer. Studies have demonstrated the ecological importance of these systems with nitrogen loss by nitrification, and increased biological productivity caused by deep waters out cropping ${ }^{[24,51-53]}$.

Table 1 depicts the environmental parameters in Arraial do Cabo sampling sites. Through a seasonal overview, the samples collected during spring and summer periods, were characterized by temperatures below $21^{\circ} \mathrm{C}$, higher dissolved oxygen value, concentration of nutrients and chlorophyll-a concentration and salinity variation between 34 and 35 indicating the rise of South Atlantic Central Water (SACW). In the other hand, autumn and winter periods presented temperatures above $21^{\circ} \mathrm{C}$, salinity between 33 and 34 and lower dissolved oxygen values, nutrients (nitrate and phosphate) and chlorophyll-a.

Table 1: Description, by sampling station, of environmental parameters in Arraial do Cabo, coastal region of Rio de Janeiro State, Brazil.

\begin{tabular}{|l|l|l|l|l|l|}
\hline \multirow{2}{*}{ Sample group and parameter } & \multicolumn{5}{|c|}{ Results } \\
\cline { 2 - 6 } & AC571 & AC582 & AC581 & AC570 & AC561 \\
\hline Water temp. (0C) & $18.1-23.3$ & $18.4-22.8$ & $17.4-24.1$ & $17.6-23$ & $19.1-23.6$ \\
\hline pH & $8.2-8.55$ & $8.11-8.41$ & $8.13-8.46$ & $8.14-8.42$ & $8.15-8.4$ \\
\hline Salinity (\%0) & $33.5-34.6$ & $33.5-34.5$ & $33.3-34.6$ & $33.4-34.5$ & $33.1-34.6$ \\
\hline Conductivity (mS) & $46.1-51.7$ & $48.3-50.8$ & $47.4-51.1$ & $48.2-50.8$ & $48.7-51.4$ \\
\hline $\mathbf{O}_{\mathbf{2}}(\mathbf{m L l i t e r})$ & $6.1-11.6$ & $6.2-10.8$ & $5.8-8.78$ & $6.6-9.8$ & $6.6-9.4$ \\
\hline Ammonium $(\boldsymbol{\mu M})$ & $1.69-3.84$ & $2.07-2.73$ & $2.56-5.98$ & $2.64-4.24$ & $1.35-2.5$ \\
\hline Nitrite $(\boldsymbol{\mu M})$ & $0.08-1.14$ & $0.07-1.18$ & $0.16-4.13$ & $0.23-1.17$ & $0.03-0.75$ \\
\hline Nitrate $(\boldsymbol{\mu M})$ & $1.21-12.67$ & $0.94-12.04$ & $1.25-12.63$ & $3.8-10.39$ & $0.63-10.68$ \\
\hline Phosfate $(\boldsymbol{\mu M})$ & $0.08-0.7$ & $0.11-0.53$ & $0.16-3.41$ & $0.06-2.09$ & $0.09-0.5$ \\
\hline Chl.a $\left(\boldsymbol{\mu g} \mathbf{L}^{-1}\right)$ & $0.46-3.49$ & $0.54-2.7$ & $1.01-7.52$ & $0.42-6.87$ & $0.47-2.86$ \\
\hline
\end{tabular}

Spatially, the highest values of inorganic nutrients and chlorophyll-a, were observed in sampling sites AC581 and AC570, both located near anthropogenic activities, such as sewage discharge and port activities. While the lowest values of these same parameters were found in location AC561, which represent the less impacted area ${ }^{[54,55]}$.

Microbial abundance observed in the Arraial do Cabo $\left(\sim 10^{7}\right.$ bacteria $\mathrm{mL}^{-1}$ and $10^{8}$ viruses $\left.\mathrm{mL}^{-1}\right)$ were in agreement with previously published values for coastal tropical waters ${ }^{[2,50,56]}$. Virioplankton abundances were highest in the same sampling sites that presented the highest levels of bacterial,in this study virus abundances ranged from 0.79 to $7.95 \times 10^{8}$.part.mL $\mathrm{mL}^{-1}$ (mean of $2.46 \mathrm{x}$ $10^{8}$.part.mL $\left.L^{-1}\right)$ (Figure 2).

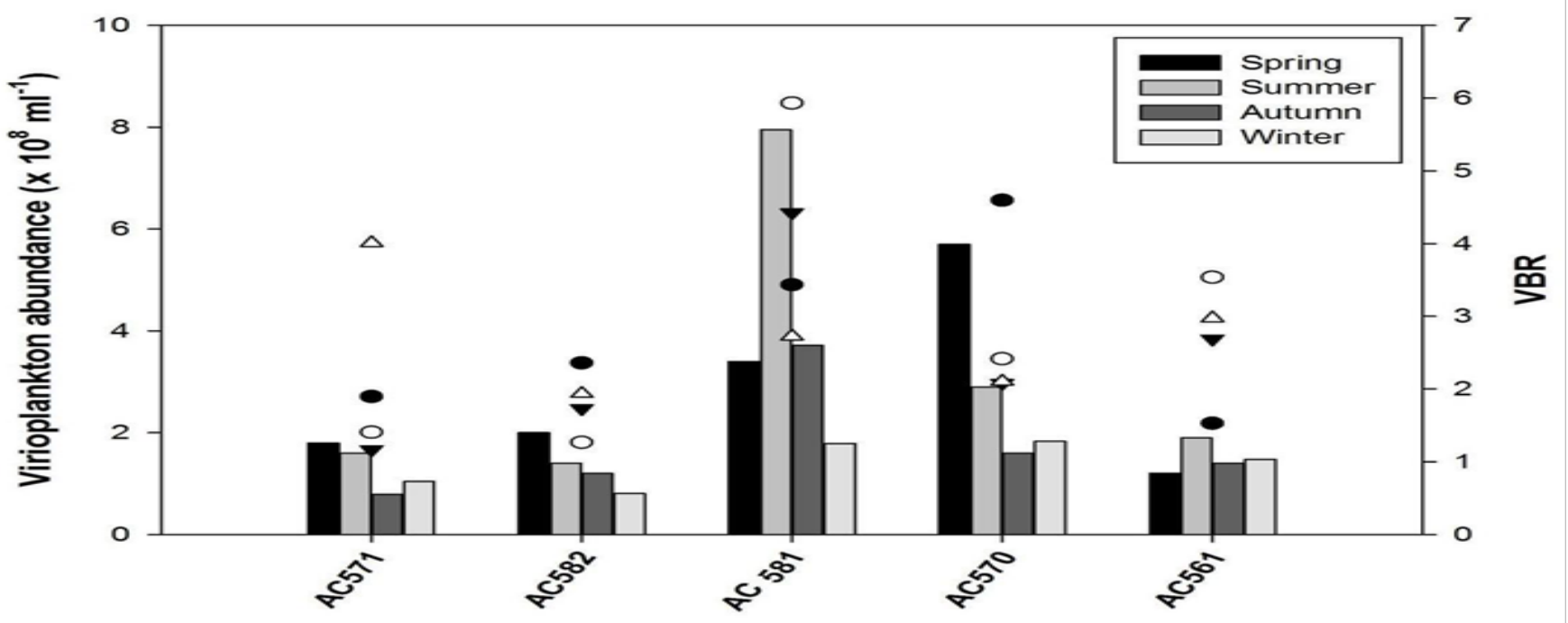

Figure 2: Mean abundance of virioplankton (columns) and VBR (solid circles - spring, open circles - summer, solid triangles - autumn, and open triangles - winter) for each sampling site in coastal region of Arraial do Cabo.

As previous studies ${ }^{[57-59]}$, we recorded significant seasonal change in virioplankton abundance related to temperature, with higher viral concentrations during spring and mainly in summer period, ranging from 1.47 to $7.95 \times 10^{8}$.part.mL $\mathrm{mL}^{-1}$ (mean of 3.61 $\pm 2.74 \times 10^{8}$. part.mL $\mathrm{mL}^{-1}$ ) with the peak of Upwelling phenomenon occurrence and lower concentrations during autumn and winter, 
means of $1.9 \pm 1.13 \times 10^{8}$.part.mL ${ }^{-1}$ and $1.37 \pm 0.45 \times 10^{8}$. part. $\mathrm{mL}^{-1}$, respectively. This seasonal behaviour was also found by Pereira et $\mathrm{al}^{[24]}$, in the same upwelling area, however with lower averages of virus abundance ranged from $6.21 \times 10^{5}$.part.mL $\mathrm{mL}^{-1}$ to $2.86 \mathrm{x}$ $10^{6}$.part. $\mathrm{mL}^{-1}$. According to the present result we suggest that upwelling phenomenon could be exerting influence on the viral abundance through the resuspension produced by ACAS bringing to the surface viruses, in addition to organic matter and possible host cells ${ }^{[60,61]}$.

According to the location sites AC581 (4.44 $\pm 2.62 \times 10^{8}$.part.mL $\left.\mathrm{mL}^{-1}\right)$ and AC570 (3.23 $\pm 1.87 \times 10^{8}$.part.mL $\left.{ }^{-1}\right)$ both influenced by anthropogenic activities presented higher virus abundance than in the other three sampling sites (one-way ANOVA; $\mathrm{p}<$ 0.001). It is assumed that more viruses are produced when conditions favour high host growth and production rates ${ }^{[62]}$. Previous works noticed a decreased in virus abundance with decreasing trophic status ${ }^{[63,64]}$. So followed by results above we could verify that both anthropic activities and upwelling phenomenon in Arraial do Cabo region represent important sources of nutrient input implying on increasing of the productivity and consequently in the increased amount of viruses in this peculiar aquatic ecosystem.

The virus to bacteria ratios (VBR) observed in this study (1.17 to 5.93) didn't fell in the range of values recorded for tropical waters, once we found a low VBR ratio (Figure 2). One of the reasons to explain this fact could be a non-significant rate of infection, either a low number of viruses by host cell, or high virus decay rate ${ }^{[17,56]}$. Besides those, another alternative hypothesis for the low VBR may be due specifically to viral infection on its host ${ }^{[65,66]}$.

Our research also employed a valuable tool to study viral communities, a method based on adsorption-elution with negatively charged membranes to concentrate viral particles present in seawater samples, a necessary step for virus isolation, which can also be used as a step for viral community's molecular analyses ${ }^{[28,58]}$. Through this technique established by Katayama et al ${ }^{[47]}$, used in a number of studies ${ }^{[26-28]}$ to concentrate viruses in order to obtain virus-free water and viral concentration to observe viral abundance and its distribution from different aquatic systems. Thus, this method allowed us to identify that in our study area the dominant virioplankton capsid diameter was found in the range of $30-60 \mathrm{~nm}$, and this result is in agreement with other studies ${ }^{[56,67-69]}$, suggesting according to virus capsid diameter and morphological data that most virus that we obtained in this study were tailed phages of the Myoviridae and Podoviridae families (Figure 3), both belonging to the Caudovirales order, which represent the most abundant phages in nature, and account for $96 \%$ of the phages described so far ${ }^{[70]}$.

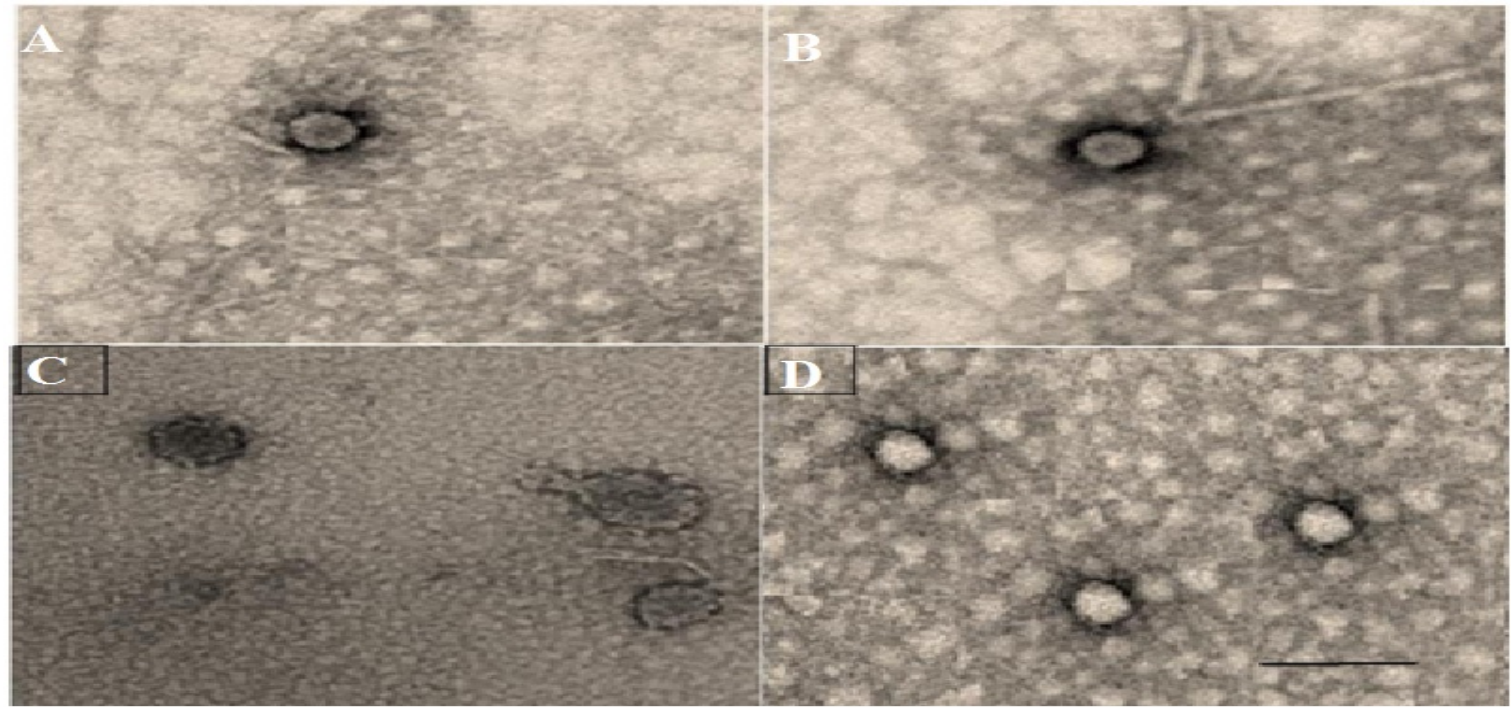

Figure 3: Transmission electron micrographs of negatively stained phages isolated from seawater obtained from Arraial do Cabo. (A) Myoviridae and (B) Podoviridae families isolated from AC581 (Anjos Bay). Myoviridae and Podoviridae families (C) isolated from AC570 (Forno Bay) and other morphologicalvirioplankters (D). Electron micrographs were taken using a transmission electron microscope and negatively contrasted with $2 \%$ uranyl acetate dihydrate. Bar, $100 \mathrm{~nm}$.

Correlation analyses showed in Table 2 highlighted a strong correlation found between viral and bacterial abundance as reported in a majority of other studies ${ }^{[2,64,71]}$; taken together $(\mathrm{r}=0.65, \mathrm{n}=20, p<0.01)$ or separated by season $\left(\mathrm{r}_{\text {spring-summer }}=0.60, \mathrm{n}=\right.$ $20, p<0.01) ; \mathrm{r}_{\text {autumn-winter }}=0.56, \mathrm{n}=20, p<0.05$ ), our results confirmed that bacterial abundance was a good predictor variable for virus in the upwelling region of Arraial do Cabo. According to previous work where abundance of virus and bacteria are correlated, most of the viruses present within research locations are considered bacteriophages ${ }^{[30,36,58,59,63]}$.

Another relevant result on the same direction aimed to results of previous works ${ }^{[6,69]}$ was the Positively correlation between virus and chlorophyll-a $(\mathrm{r}=0.61, p<0.01)$ (Table 2). This strong correlation between chlorophyll-a concentration and virus supports a significant correlationbetween bacterial production and virioplankton abundance, as higher levels of chlorophyll-aindicate a more productive system increasing bacterial abundance, and also indirectly viral abundance ${ }^{[35,63]}$. A possible explanation for this observation is due to the fact that tropical ecosystems chosen for this work contain high concentrations of algae and cyanobacteria increasing phytoplankton biomass, and consequently more algal viruses ${ }^{[63,72]}$. These data can be linked to the fact that bacteria and phytoplankton comprises the major viral host and consequently they are subjected to viral infection ${ }^{[44,73,74]}$. 
Study of virioplankton Abundance \& Morphological Diversity

Table 2: Two-tailed Pearson product-moment correlation between abiotic and biotic variables in the five sampling sites of Arraial do Cabo through four different seasons.

\begin{tabular}{|c|c|c|c|c|c|c|c|c|c|c|c|c|c|}
\hline Variable & Temp & $\mathrm{pH}$ & Sal & Cond & OD & $\mathrm{NH}_{4}$ & $\mathrm{NO}_{2}$ & $\mathrm{NO}_{3}$ & $\mathrm{PO}_{4}$ & $\mathrm{~N}: \mathrm{P}$ & Chl-a & Bacteria & Virus \\
\hline \multicolumn{14}{|l|}{ Temp } \\
\hline $\mathrm{pH}$ & $* \mathrm{Neg}$ & & & & & & & & & & & & \\
\hline Sal & $* * *$ & - & & & & & & & & & & & \\
\hline Cond & $* *$ & $* * \mathrm{Neg}$ & $* * *$ & & & & & & & & & & \\
\hline O.D & $* \mathrm{Neg}$ & $* * *$ & - & $*$ Neg & & & & & & & & & \\
\hline $\mathrm{NH}_{4}$ & - & - & - & $* * N e g$ & - & & & & & & & & \\
\hline $\mathrm{NO}_{2}$ & $*$ Neg & - & - & *Neg & - & - & & & & & & & \\
\hline $\mathrm{NO}_{3}$ & $* * *$ Neg & $*$ & $* * *$ Neg & $* * *$ Neg & - & - & $* *$ & & & & & & \\
\hline $\mathrm{PO}_{4}$ & $* *$ Neg & - & *Neg & $*$ & - & - & $* * *$ & $* *$ & & & & & \\
\hline $\mathrm{N}: \mathrm{P}$ & - & - & - & - & - & - & - & - & *Neg & & & & \\
\hline Chl-a & $* * * N e g$ & - & $* * \mathrm{Neg}$ & $* *$ Neg & - & - & $* *$ & $* *$ & $* * *$ & - & & & \\
\hline Bacteria & $* * * N e g$ & - & *Neg & $* * *$ Neg & - & - & $* *$ & $* * *$ & $* *$ & - & $* * *$ & & \\
\hline Virus & - & - & - & - & - & - & $* * *$ & $*$ & $* * *$ & - & $* *$ & $* *$ & \\
\hline
\end{tabular}

$* * * \mathrm{p}<0.001 ; * \mathrm{p}<0.01 \mathrm{e}^{*} \mathrm{p}<0.05$.

Additionally, virioplankton present a negative correlation to temperature $(r=-0.43, n=20)$, to salinity $(r=-0.39$, $n=$ $20)$ and to conductivity $(r=-0.42, n=20)$, suggesting that upwelling process may be one of the factors that could controls virus abundance in AC region (Table 2). Previous works also verified a decreased in virus abundance with increasing salinity ${ }^{[57,64]}$ and temperature ${ }^{[61]}$.

In relation to nutrients, a high correlation between virus and nitrite $(\mathrm{r}=0.81, \mathrm{n}=20, \mathrm{p}<0.001)$, virus and nitrate $(\mathrm{r}=0.55$, $\mathrm{n}=20, p<0.05)$ and virus and phosphate $(\mathrm{r}=0.79, \mathrm{n}=20, p<0.001)$ were observed (Table 2$)$. Once nutrients can stimulate bacterial growth ${ }^{[75-78]}$, and indirectly increaseviral abundance, they could be sensitive to nitrate and phosphate. Interestingly, in relation to nitrogen forms, viral and bacterial abundance were more highly correlated to nitrate during warmer periods, once high levels of DO favoured nitrification. This fact may be linked to the upwelling Phenomenon that happens in later spring and summer.

The variation of physical-chemical and biological parameters was also analyzed using principal component analysis (PCA $)^{[79,80]}$ providing robustness to data correlation. Data matrix included 20 samples from Arraial do Cabo over different seasons (Figure 4), and analyzed a total of 13 variables (seawater temperature, $\mathrm{pH}$, salinity, conductivity, dissolved oxygen, ammonia, nitrite, nitrate, phosphate, N:P ratio, chlorophyll-a, bacteria and viruses). Relationship between allmeasured variables, using PCA, showed that the first and second axis have been together able to explain the majority of the total variance observed in this study (71.52\%). Thus, the first axis analyses ( $\mathrm{PC} 1)$ showed that nitrogen inorganic forms $\left(\mathrm{NO}_{2}-\right.$ and $\left.\mathrm{NO}_{3}-\right)$, chlorophyll-a, bacteria, $\mathrm{PO}_{4}^{3-}$, viruses, $\mathrm{pH}$ and DO, had positive loadings. In contrast, temperature, salinity, conductivity, and N:P ratio had negative loadings. This first principal component summarizes the seasonal effects evidenced on bacterioplankton and virioplankton distribution presented by a clear division between the warmer seasons (Group I) and the colder seasons (Group II).

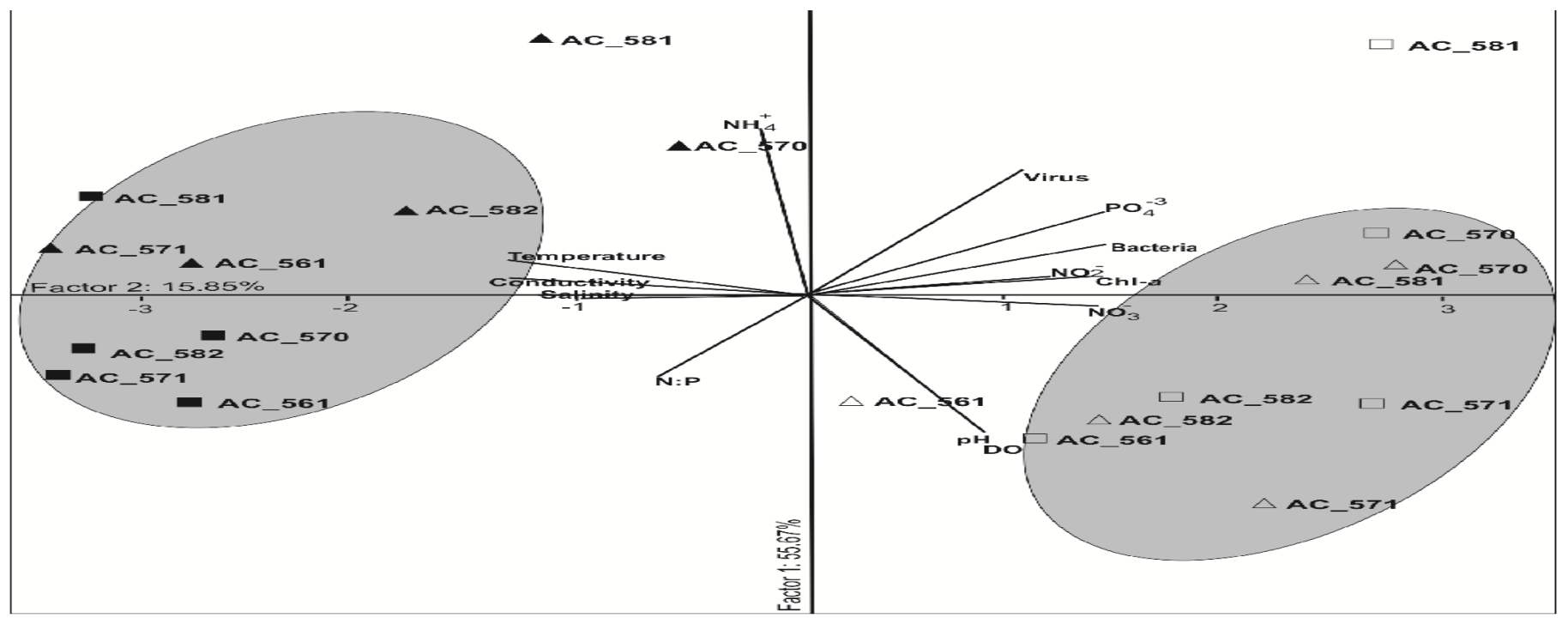

Figure 4: PCA analysis of biotic and abiotic variables in Arraial do Cabo. There is a clear seasonal division between Group 1 (warmer seasons) and Group 2 (colder seasons). The different seasons are represented by open triangles - spring, open squares - summer, solid triangles - autumn, and solid squares - winter. 
The PCA provided a noteworthy biotic (bacteria and chlorophyll-a) and abiotic factors such as temperature, $\mathrm{pH}$, salinity, conductivity, dissolved oxygen data and also nutrient availability that can influence viral distribution and abundance in Arraial do Cabo region. Previous works in the ocean have also showed that viral distribution and abundance could be controlled by environmental factors ${ }^{[71,81,82]}$.

This multivariate analysis also showed a clear seasonal separation between the sampling spring- summer versus autumn-winter periods (Figure 4). According to this correlation results, we can suggest that the distribution of virioplankton abundances could also be defined by different water masses characteristics, which may influence higher abundances of their possible hosts, mainly in warmer periods. This data is in accordance with other seasonal studies that showed higher numbers during the warm periods of summer and spring ${ }^{[57,83]}$. In fact, our study demonstrated that virus abundance in Arraial do Cabo upwelling area appears to vary slightly more seasonally than in a spatial scale mode. This fact could be explained specially because Arraial do Cabo undergoes the upwelling phenomenon during spring-summer periods when we observed higher viral numbers compared to numbers observed during the absence of this phenomenon.

However, the spatial and seasonal distribution of virioplankton on Arraial do Cabo did not have significant variation between sampling stations or different seasons (ANOVA, $p>0.05$ ). Interestingly, all five sampling sites had a high similar trend in virioplankton, bacterioplankton and chlorophyll-a increase on summer and spring periods. However, bacterioplankton and concentration of chlorophyll-a were significantly influenced by seasonality (ANOVA, $p<0.05$ ), showing a high decrease from summer-spring to winter-autumn samples.

Table 3: Spatial and seasonal ANOVA ${ }^{1}$ analysis on viral and bacterial abundances and virus- bacterium ratio (VBR) samples from Arraial do Cabo.

\begin{tabular}{|c|c|c|c|c|c|c|c|c|c|c|c|c|}
\hline \multirow[t]{2}{*}{ Parameters } & \multicolumn{4}{|c|}{ Virus } & \multicolumn{4}{|c|}{ Bacteria } & \multicolumn{4}{|c|}{ Chlorophyll-a } \\
\hline & SS & DF & $\mathbf{F}$ & $P$ & SS & DF & $\mathbf{F}$ & $\boldsymbol{P}$ & SS & DF & $\mathbf{F}$ & $\boldsymbol{P}$ \\
\hline Site & 26.52 & 4 & 3.02 & 0.05 & 46.28 & 4 & 1.41 & 0.27 & 33.47 & 4 & 2.35 & 0.100 \\
\hline Season & 10.64 & 3 & 1.15 & 0.35 & 91.64 & 3 & 6.29 & 0.00 & 52.65 & 3 & 8.22 & 0.001 \\
\hline
\end{tabular}

${ }^{1} \mathrm{SS}$, sum of squares; DF, Degrees of freedom; F, F-distribution value; $P$, p value.

Significant differences in spatial and seasonal analyses (ANOVA, $p<0.05$ ) were detected for all physical and chemical parameters, and the Tukey test among stations and seasons highlighted the significant differences (data not shown). Spatially biotic analyses indicated that no significant difference was observed in viral, bacterial and chlorophyll-a concentrations between the different sampling stations of Arraial do Cabo (ANOVA, $p>0.05$ ). Whereas in seasonal data only viruses have no differences in their abundance, (ANOVA, $p>0.05$ ) just bacteria and chlorophyll-a (ANOVA, $p<0.05$ ) (Table 3). Additionally, no significant statistic difference in VBR was found both spatially and seasonally (ANOVA, $p>0.05$ ).

\section{Conclusion}

In conclusion, the integration of all data allowed us to indicate that the abundance of viruses in the Arraial do Cabo upwelling region was positively influenced by both biotic factors, such as bacteria and chlorophyll-a, as well as abiotic factor, mainly nitrogen inorganic forms $\left(\mathrm{NO}_{2}-\right.$ and $\mathrm{NO}_{3}-$ ) and $\mathrm{PO}_{4}^{3-}$. Correlation of virus with bacteria and chlorophyll-a suggests these cells were the principal hosts and supported the viral distribution and abundance.

\section{References}

1. Berg, O., Borsheim, K.Y., Bratbak, G. et al. High abundance of viruses found in aquatic environments. (1989) Nature 340(6233): 467-468.

2. Wommack, K.E., Colwell, R.R. Virioplankton: viruses in aquatic ecosystems. (2000) Microbiol Mol Biol Rev 64(1): 69-114.

3. Breitbart, M., Rohwer, F. Here a virus, there a virus, everywhere the same virus? (2005) Trends Microbiol 13(6): 278-284.

4. Bettarel,Y., Bouvy, M., Dumont, C., et al. Virus-bacterium, interactions in Water and Sediment of West African Inland aquatic systems. (2006) Appl Environ Microbiol 72(8): 5274-5282.

5. Brussaard, C.P., Wilhelm, S.W., Thingstad, F., et al. Global-scale processes with a nanoscale drive: the role of marine viruses. (2008) ISME J 2(6): 575-578.

6. Rohwer, F., Thurber, R.V. Viruses manipulate the marine environment. (2009) Nature 459(7244): 207-212.

7. Sime-Ngando, T., Bettarel, Y., Chartogne, C., et al. The imprint of wild viruses on fresh water microbial ecology. (2003) Recent 
Res Dev Microbiol 7: 481-497..

8. Säwström, C., Graneli, W., Laybourn-Parry, J., et al. High viral infection rates in Antarctic and Arctic bacterioplankton. (2007) Environ Microbiol 9(1): 250-255.

9. Parsons, R.J., Breitbart, M., Lomas, M.W., et al. Ocean time-series reveals recurring seasonal patterns of virioplankton dynamics in the northwestern Sargasso Sea. (2011) ISME J 6(2): 273-284.

10. Breitbart, M. Marine Viruses: Truth or Dare. (2012) Ann Rev Mar Sci 4: 425-448.

11. Angly, F.E., Felts, B., Breitbart, M., et al. The marine viromes of four oceanic regions. (2006) PLoS Biol 4(11): e368.

12. Säwström, C., Ask, J., Karlsson, J. Viruses in subarctic lakes and their impact on benthic and pelagic Bacteria. (2009) FEMS Microbiol Ecol 70(3): 471-482.

13. Winter, C., Payet, J.P., Suttle, C.A. Modeling the winterto-summer transition of prokaryotic and viral abundance in the Arctic Ocean. (2012) PLoS One 7(12): e52794.

14. Kepner, R.L., Wharton, R.A., Suttle, C.A. Viruses in Antarctic lakes. (1998) Limnol Oceanogr 43(7): 1754-1761.

15. Boehme, J., Frischer, M.E., Jiang, S.C., et al. Viruses, bacterioplankton, and phytoplankton in the southeastern Gulf of Mexico: distribution and contribution to oceanic DNA pools. (1993) Mar Ecol Prog Ser 97: 1-10.

16. Rusch, D.B., Halpern, A.L., Sutton, G., et al. The Sorcerer II Global Ocean Sampling expedition: Northwest Atlantic through eastern tropical Pacific. (2007) PLoS Biol 5(3): e77.

17. Chiang, O.E., Quiñones, R.A. Relationship between viral and prokaryotic abundance on the Bajo O'Higgins 1 Seamount (Humboldt Current System off Chile). (2007) Sci Mar 71(1): 37 46.

18. Arslan, D., Legendre, M., Seltzer, V., et al. Distant Mimivirus relative with a larger genome highlights the fundamental features of Megaviridae. (2011) Proc Natl Acad Sci USA 108(42): 17486-17491.

19. Lee, C.W., Bong, C.W. Relative contribution of viral lysis and grazing to bacterial mortality in tropical coastal waters of Peninsular Malaysia. (2012) Bull Mar Sci 88(1): 1-14.

20. Pedroso, D.M.M., Martins, M.T. Ultra-morphology of coliphages isolated from water. (1995) Water Res 29(4): 1199-1202.

21. BurbanoRosero, E.M., Ueda-Ito, M., Kisielius, J.J., et al. Diversity of somatic coliphages in coastal regions with different levels of anthropogenic activity in São Paulo State, Brazil. (2011) Appl Environ Microbiol 77(12): 4208-4216.

22. Barros, N., Farjalla, V.F., Soares, M.C., et al. Virus-bacte- rium coupling driven by both turbidity and hydrodynamics in an Amazonian floodplain lake. (2010) Appl Environ Microbiol 76(21): 7194-7201.

23.Gimenes, M.V., Zanotto, P.M., Suttle, C.A., et al. Phylodynamics and movement of phycodnaviruses among aquatic environments. (2012) ISME J 6(2): 237-247.

24. Pereira, G.C., Granato, A., Figueiredo, A.R., et al. Virioplankton abundance in trophic gradients of an upwelling Field. (2009) Braz J Mirobiol 40(4): 857-865.

25. Santos, C.S., Rigotto, C., Simões, C.M.O., et al. Improved method for rotavirus detection in oysters using RT-PCR: suitable of commercial PCR kit. (2001) J Shellfish Res 20: 997-1002.

26. Tavares, T.M., Cardoso, D.D.P., De Brito, W.M.E.D. VírusEntéricosVeiculados PorÁgua: Aspectos Microbiológicos e de Controle de Qualidade da Água. (2005) Revista de PatologiaTropical 34(2): 85-104.

27. De Paula, V.S., Diniz-Mendes, L., Villar, L.M., et al. Hepatitis $A$ virus in environmental water samples from the Amazon basin. (2007) Water Res 41(6): 1169-1176.

28. Miagostovich, M.P., Ferreira, F.F.M., Guimarães, F.R., et al. Molecular detection and characterization of gastroenteritis viruses occurring naturally in the stream waters of Manaus, Central Amazonia, Brazil. (2008) Appl Environ Microbiol 74(2): 375-382.

29. Victoria, M., Rigotto, C., Moresco, V., et al. Assessment of norovirus contamination in environmental samples from Florianópolis City, Southern Brazil. (2010) J Appl Microbiol 109(1): 231-238.

30. Proctor, L.M., Fuhrman, J.A. Viral mortality of marine bacteria and cyanobacteria. (1990) Nature 343: 60-62.

31. Wilhelm, S.W., Suttle, C.A. Viruses as regulators of nutrient cycles in aquatic Environments -In Bell, C. R., Brylinsky, M., and Johnson-Green, P. (ed.). (1999) Microbial Biosystems: new frontiers, Proceedings of the VIII International Symposium on Microbial Ecology 551-556.

32. Suttle, C.A. Marine viruses - major players in the global ecosystem. (2007) Nat Rev Microbiol 5(10): 801-812.

33. Suttle, C.A. Viruses in the sea. (2005) Nature 437(7057): 356-361.

34. Guenther, M., Gonzalez, R.E., Carvalho, W.F., et al. Plankton trophic structure and Particulate organic carbon production during a coastal downwelling-upwelling cycle. (2008) Mar Ecol Prog Ser 363: 109-119.

35. Jacquet, S., Miki, T., Noble, R., et al. Viruses in aquatic ecosystems: important advancements of the last 20 years and prospects for the future in the field microbial oceanography and limnology. (2010) Adv Oceanogr Limnol 1(1): 97-141. 
36. Pradeep Ram, A.S., Sime-Ngando, T. Resource drive tradeoff between viral lifestyles in the plankton: evidence from freshwater microbial microcosms. (2010) Environ Microbiol 12(2): 467- 479 .

37. Valentin, J.L., Andre, D.L., Jacob, S.A. Hydrobiology in the Cabo Frio (Brazil) upwelling two-dimensional structure and variability during a wind cycle. (1987) Cont Shelf Res 7(1): 7788 .

38. Valentin, J.L. Analysis of hydrobiological parameters in the Cabo Frio (Brazil) upwelling. (1984) Mar Biol 82(3): 259-276.

39. Campos, E.J.D., Velhote, D., Silveira, I.C.A. Shelf break upwelling driven by Brazil Current cyclonic meanders. (2000) Geophys Res Lett 27(6): 751-754.

40. Pereira, G.C., Coutinho, R., Ebecken, N.F.F. Data mining for environmental analysis and diagnostic: a case of upwelling ecosystem of Arraial do Cabo. (2008) Braz J Oceanogr 56(1): 1-12.

41. Grasshoff, K., Ehrhardt, T.M., Kremling, K. Methods of seawater analysis. (1983) 2nd Ed. Weinheim: VerlagChemie, 1-419.

42.Lorenzen, C.J. Determination of chlorophyll and pheo-pigments: spectrophotometric equations. (1967) Limnol Oceanogr 12(2): 343-346.

43. Hobbie, J.E., Daley, R.J., Jasper, S. Use of nuclepore filters for counting bacteria by fluorescence microscopy. (1977) Appl Environ Microbiol 33(5): 1225-1228.

44. Noble, R.T., Fuhrman, J.A. Breakdown and microbial uptake of marine viruses and other lysis products. (1999) Aquat Microb Ecol 20: 1-11.

45. Marie, D., Brussaard, C.P.D., Thyrhaug, R., et al. Enumeration of marine viruses in culture and natural samples by flow cytometry. (1999) Appl Environ Microbiol 65(1): 45-52.

46.Brussaard, C.P.D. Optimization of procedure for counting viruses by flow cytometry. (2004) Appl Environ Microbiol 70(3): 1506-1513.

47. Katayama, H., Shimasaki, A., Ohgaki, S. Development of a virus concentration method and its application to detection of enterovirus and norwalk virus from coastal seawater. (2002) Appl Environ Microbiol 68(3): 1033-1039.

48. Ackermann, H.W., Abedon, S.T. The Bacteriophage Ecology Group: Bacteriophage names. (2000). Accessed 20 October 2015.

49. Van Regenmortel, M.H.V. Virus Taxonomy: The Classification and Nomenclature of Viruses. The Seventh Report of the International Committee on Taxonomy of Viruses. (2000)

Virus Taxonomy, VII ${ }^{\text {th }}$ report of the ICTV.

50. Rodrigues, R.R., Lorenzzetti, J.A. A numerical study of the effects of bottom topography and coastline geometry on the
Southeast Brazilian coastal upwelling. (2001) Cont Shelf Res 21: 371-394.

51. Castelao, R.M., Barth, J.A. Upwelling around Cabo Frio, Brazil: The importance of wind stress curl. (2006) Geophys Res Lett 33: 1-4.

52. Woebken, D., Fuchs, B.M., Kuypers, M.M., et al. Potential interactions of particle-associated anammox bacteria with bacterial and archaeal partners in the Namibian upwelling system. (2007) Appl Environ Microbiol 73(14): 4648-4657.

53. Cury, J.C., Araujo, F.V., Coelho-Souza, S.A, et al. Microbial diversity of a Brazilian coastal region influenced by an upwelling system and anthropogenic activity. (2011) PLoS One 6(1): e16553.

54. Almeida, M.A., Cunha, M.A., Alcantara, F. Factors influencing bacterial production in a shallow estuarine system. (2001) Microb Ecol 42(3): 416-426.

55. Schultz, G.E., Ducklow, H. Changes in bacterioplankton metabolic capabilities along a salinity gradient in the York River estuary, Virginia, USA. (2000) Aquat Microb Ecol 22(2): 163174.

56. Alonso, M.C., Jiménez-Gómez, F., Rodríguez, J., et al. Distribution of virus-like particles in an oligotrophic marine environment (Alborean sea, Western Mediterrean). (2001) Microb Ecol 42(3): 407-415.

57. Jiang, S.C., Paul, J.H. Seasonal and diel abundance of viruses and occurrence of lysogeny/bacteriocinogeny in the marine environment. (1994) Mar Ecol Prog Ser 104: 163-172.

58. Weinbauer, M.G. Ecology of prokaryotic viruses. (2004) FEMS Microbiol Rev 28(2): 127-181.

59. Auguet, J.C., Montanie, H., Delmas, D., et al. Dynamic of virioplankton abundance and its environmental control in the Charente Estuary (France). (2005) Microb Ecol 50(3): 337-349.

60. MC, Daniel, L., Paul, J.H. Effect of Nutrient Addition and Environmental Factors on Prophage Induction in Natural Populations of Marine Synechococcus Species. (2005) Appl Environ Microbiol 71(2): 842-850.

61. Bidle, K.D., Haramaty, L., Barcelos J., et al. Viral activation and recruitment of metacaspases in the unicellular coccolithophore, Emilianiahuxleyi. (2007) Proc Natl Acad Sci 104(14): 6049-6054.

62. Cochlan, W.P., Wikner, J., Steward, G.F., et al. Spatial distribution of viruses, bacteria and chlorophyll-a in neritic, oceanic and estuarine environments. (1993) Mar Ecol Prog Ser 92: 7787.

63. Maranger, R., Bird, D.F. Viral abundance in aquatic systems: a comparison between marine and freshwaters. (1995) Mar Ecol Prog Ser 121: 217-226. 
64. Hewson, I., ON, J.M., Heil, C.A., et al. Effects of concentrated viral communities on photosynthesis and community composition of co-occurring benthic microalgae and phytoplankton. (2001) Aquat Microb Ecol 25: 1-10.

65. Lenski, R.E. Dynamics of interaction between bacteria and virulent bacteriophage. (1988) Adv Microb Ecol 10: 1-44.

66. Middelboe, M. Bacterial Growth Rate and Marine Virus-Host Dynamics. (2000) Microb Ecol 40(2): 114-124.

67. Weinbauer, M.G., Peduzzi, P. Significance of viruses versus heterotrophic nanoflagellates for controlling bacterial abundance in the northern Adriatic Sea. (1995) J Plankton Res 17(9): 1851-1856.

68. Stopar, D., Cerne, A., Zigman, M., et al. Viral abundance and a high proportion of lysogens suggest that viruses are important members of the microbial community in the gulf of Trieste. (2004) Microb Ecol 47(1): 1-8.

69. Liu, Y.M., Yuan, X.P., Zhang, Q.Y. Spatial distribution and morphologic diversity of virioplankton in lake Donghu, China. (2006) Acta Oecologica 29(3): 328-334.

70. Gregoracci, G. B., Silveira, W. D., Brocchi, M. The biology of bacteriophages. (2006) In: WEGRZYN, G. Modern Bacteriophage Biology and Biotechnology. Research Signpost, 1-36.

71. Corinaldesi, C., Crevatin, E., Negro, P.D., et al. Large-scale spatial distribution of virioplankton in the Adriatic Sea: testing the trophic state control hypothesis. (2003) Appl Environ Microbiol 69(5): 2664-2673.

72. Rowe, J.M., Saxton, M.A., Cottrell, M.T., et al. Constraints on viral production in the Sargasso sea and North Atlantic. (2008) Aquat Microb Ecol 52: 233-244.

73. Wilson, W.H., Mann, N.H. The effect of phosphate status on virus populations during a mesocosm study: In Bratbak, G. and Thingstad, F. 5th Ed. (1996) European Microbial Ecology Symposium, Bergen, Norway: 77.
74. Middelboe, M., Jacquet, S., Weinbauer, M. Viruses in freshwater ecosystems: an introduction to the exploration of viruses in new aquatic habitats. (2008) Freshwater Biology 53(6): 10691075.

75. Riemann, L., Middelboe, M. Stability of bacterial and viral community compositions in Danish coastal waters as depicted by DNA fingerprinting techniques. (2002) Aquat Microb Ecol 27: 219-232.

76. Weinbauer, M.G., Brettar, I., Höfle, M.G. Lysogeny and virus-induced mortality of bacterioplankton in surface, deep, and anoxic marine waters. (2003) Limnol Oceanogr 48(4): 14571465.

77. Middelboe, M. Microbial disease in the sea: effects of viruses on carbon and nutrient cycling. (2008) In Infectious Disease Ecology: Effects of Ecosystems on Disease and of Disease on Ecosystems 242-259.

78. Riemann, L., Holmfeldt, K., Titelman, J. Importance of viral lysis and dissolved DNA for bacterioplankton activity in a P-limited estuary, Northern Baltic Sea. (2008) Microb Ecol 57(2): 286-294.

79. James, F., McCulloch, C. Multivariate analysis in ecology and systematics: Panacea or Pandora's box? (1990) Ann Rev Ecol Syst 21: 129-166.

80. Tabachnick, B.G., Fidell, L.S. Using multivariate statistics. (2007) Harper Collins Publishers.5th edition: 1-980.

81. Winter, C., Smit, A., Szoeke-Denes, T., et al. Modelling viral impact on bacterioplankton in the North Sea using artificial neural networks. (2005) Environ Microbiol 7(6): 881-893.

82. Rohwer, F., Prangishvili, D., Lindell, D. Roles of viruses in the environment. (2009) Environ Microbiol 11(11): 2771-2774.

83. Personnic, S., Domaizon, I., Dorigo, U., et al. Seasonal and spatial variability of vireo-, bacterio- and picophytoplanktonic abundances in three peri-alpine lakes. (2009) Hydrobiologia 627(1): 99-116.
Ommega Online Publishers

Journal Title: Journal of Marine Biology and Aquaculture Journal Short Name: J Marine Biol Aquacult
Journal ISSN 2381-0750

E-mail: marinelife@ommegaonline.org

Website:_www.ommegaonline.org 